\title{
Qualitative Assessment of Table Salt Production Techniques in Southern Benin Republic, and Related Mangrove Destruction and Health Issues
}

\author{
Julien Adounkpe1*, Cyriaque Agboton², Waliou Amoussa Hounkpatin³, \\ Basile Kounouhewa4, Clement Ahouannou ${ }^{5}$, Brice Sinsin'1
}

\author{
${ }^{1}$ Laboratory of Applied Ecology, LEA, Faculty of Agronomic Sciences, University of Abomey-Calavi, Abomey-Calavi , \\ Republic of Benin \\ ${ }^{2}$ International Institute of Tropical Agriculture, IITA, Republic of Benin \\ ${ }^{3}$ Laboratory of Human Nutrition, LNH, Faculty of Agronomic Sciences, University of Abomey Calavi, Abomey Calavi, \\ Republic of Benin \\ ${ }^{4}$ Laboratoire de Physique de Rayonnement, LPR, Faculté des Sciences et Techniques, Université d'Abomey Calavi, Abomey Calavi, \\ Republic du Benin \\ ${ }^{5}$ Laboratoire d'Energétique et de Mécanique Appliquée, Ecole Polytechnique d'Abomey Calavi, Universite d'Abomey Calavi, \\ Abomey Calavi, Republic of Benin \\ Email: *julvictoire@yahoo.com, c.agboton@cgiar.org, amouswal@yahoo.fr, \\ kbbasile@gmail.com, ahouannouc@gmail.com,bsinsin@gmail.com
}

How to cite this paper: Adounkpe, J., Agboton, C., Hounkpatin, W.A., Kounouhewa, B., Ahouannou, C. and Sinsin, B. (2021) Qualitative Assessment of Table Salt Production Techniques in Southern Benin Republic, and Related Mangrove Destruction and Health Issues. Food and Nutrition Sciences, 12, 759-773.

https://doi.org/10.4236/fns.2021.127057

Received: May 29, 2021

Accepted: July 17, 2021

Published: July 20, 2021

Copyright $\odot 2021$ by author(s) and Scientific Research Publishing Inc. This work is licensed under the Creative Commons Attribution International License (CC BY 4.0).

http://creativecommons.org/licenses/by/4.0/

\begin{abstract}
This research was conducted in the framework of the feasibility study related to FOCUSED-Benin project, the $5^{\text {th }}$ work package of the YES-PV NIG BEN project financed by the German Government through its Ministry of Research and High Education (BMBF). The FOCUSED Benin project's major objective is to protect the environment through the utilization of solar energy for drying agricultural products and table salt harvesting. Salt is important in human daily life. It is used for conservation of food, softening water, industrial processes, road de-icing, food seasoning, etc. Seawater evaporation, salt mining, and salt brine are the major sources of salt production worldwide. However, in West Africa, particularly in Benin Republic, table salt is produced using methods that negatively impact the ecology of the mangrove. This study aimed at investigating the current status of salt production in $\mathrm{Be}$ nin Republic, its impact on the mangrove and its related health issues. Field visits, meeting with associations of women salt producers in the coastal region of the country, allowed to quantify the number of women associations dealing with salt production, their difficulties, and the impacts on the mangrove. Salt is
\end{abstract}


a seasonal activity and is produced from January to May. One kilogram salt production, along with health issues reported by salt producers, requires approximately $1 \mathrm{~kg}$ of firewood obtained by cutting down mangrove. Salt price varies from 250CFA (€0.38) to 400FCFA (€0.61) per $\mathrm{kg}$ depending on the season. The women salt producers are not aware of the ecological consequences of mangrove destruction. Sources of firewood are becoming increasingly scarce and prices prohibitive. Sensitization is not efficient. An alternative method of harvesting salt by solar drying and new ideas for implementing this activity in a participatory approach was discussed with the different associations of salt producers.

\section{Keywords}

Table Salt, Brine, Seawater Ecology, Mangrove, Health Issues

\section{Introduction}

Salt is used across cultures and industries. It has held an important place in society for over several millennia [1] [2]. Per its capacity to enhance flavor and mask bitterness, salt is the most commonly used seasoning across the globe [3]. However, its consumption in various diets, if exaggerated, is a serious threat to human health. One of the primary electrolytes in the human body, excessive sodium (hypernatremia) or insufficient sodium (hyponatremia), leads to various illness presentations. Excessive salt intake is associated with hypertension. Research has found that people with high normal blood pressure who significantly reduced dietary salt intake can reduce the risk of cardiovascular disease by $25 \%$ over the following 10 to 15 years, and the risk of dying from cardiovascular disease is reduced by $20 \%$. Excessive sodium is also associated with left ventricular hypertrophy and kidney Diseases [4] [5] [6]. When possible, adverse effects of sodium overconsumption were examined by the Panel on Dietary Reference Intakes for Electrolytes and Water, evidence on cardiovascular outcomes (stroke, coronary heart disease, left ventricular hypertrophy) and kidney disease and their association with increased blood pressure were pointed out [7]. The dietary guideline in the United States recommends consumption of less than $2.3 \mathrm{~g}$ of sodium per day, approximately 1 tea spoon full of salt [8].

Beside its culinary uses, salt is used for softening water, de-icing roads, and it is used in agriculture, for industrial processes including the manufacture of polychlorinated vinyl plastics and paper pulp and in the pharmaceutical industry [2] [9]. According to a study by the Freedonia Group the world salt demand is in a constant rise ranging from 282.0 million metric tons, 304.7 million metric tons, and 335.0 million metric tons respectively in 2010, 2015 and 2020 and is forecasted to reach 346 million metric tons in 2023 [10]. The share for Africa/ Mideast is 15.0, 18.0, and 21.7 million metric tons, respectively, in 2010, 2015, and 2020 , and represents $5.32 \%, 5.90 \%$, and $6.48 \%$ respectively.

Worldwide, the major sources of salt are through the evaporation of seawater, 
mining rocky salt formations within the earth, and creating salt brines [11]. Table salt consumption in various diets is largely derived from salt brines. Specialty or gourmet salts will more often come from seawater evaporations, whereas the majority of salt produced through mining is industrially used [4] [12].

However, in the coastal region of Benin Republic (West Africa), in addition to seawater evaporation, cooking salt producers have other traditional methods for table salt harvesting. These methods need to be investigated and studied for two major reasons, both sanitary and environmentally, in order to propose sanitary and environmental improvements. As for the sanitary aspects of cooking salt harvesting in Benin Republic, the hygiene of the harvesting method is questionable. The observation of some basic hygienic measures seems to be of little concern to the cooking salt producers. In addition, women salt harvesters are subject to several health challenges that put their lives at risk. For the environmental improvement part of this study, the vast majority of cooking salt harvesters uses wood for salt water evaporation. It was found that from 2005 to 2015, a decrease of about $2.49 \%$ in mangrove surface area is due to salt harvesting activities [13]. This put high pressure on the mangroves of the southern region of the country [14]. However, mangrove renders several environmental services. Besides being a habitat to the aquatic living organisms, coastal erosion protecting means, mangroves also have global climate change mitigation benefits, providing carbon storage in biomass and soils and habitat for maintaining biodiversity. It is reported that mangroves, worldwide, can store as much as $14-73$ billion metric tons of carbon dioxide equivalent $\left(\mathrm{tCO}_{2} \mathrm{e}\right)$, including aboveground and belowground biomass and soil carbon [15]. In comparison, the annual global carbon dioxide $\left(\mathrm{CO}_{2}\right)$ emissions in 2014 were 49 billion metric tons [16]. It was also estimated that undisturbed mangroves can sequester $6.38 \mathrm{tCO}_{2} /$ ha per year [17] and that a primary mangrove forest on the northern coast of Kenya contains up to $500 \mathrm{tC} / \mathrm{ha}$ of aerial and underground components. For this important $\mathrm{CO}_{2}$ sequestration capacity of the mangrove, the African Mangrove Network plays an important role for its conservation [18].

Mangroves typically provide some protection from extreme coastal events, such as tsunamis and cyclones. It was estimated that an eight percent reduction in the severity of impacts of the 2004 tsunami in coastal areas is due to mangroves [19].

Among others, table salt production in Southern Benin Republic is one of the leading causes of mangrove destruction [13]. The present study, by investigating the traditional table salt production in six municipalities of South Benin Republic, attempts to report on salt harvesting techniques, difficulties and challenges as well as the impacts of this socio-economic activity on the mangrove and the related health issues.

\section{Materials and Methods}

\subsection{Area of Study}

Figure 1 depicts the six municipalities where table salt is produced in the southern Benin Republic, West Africa. 


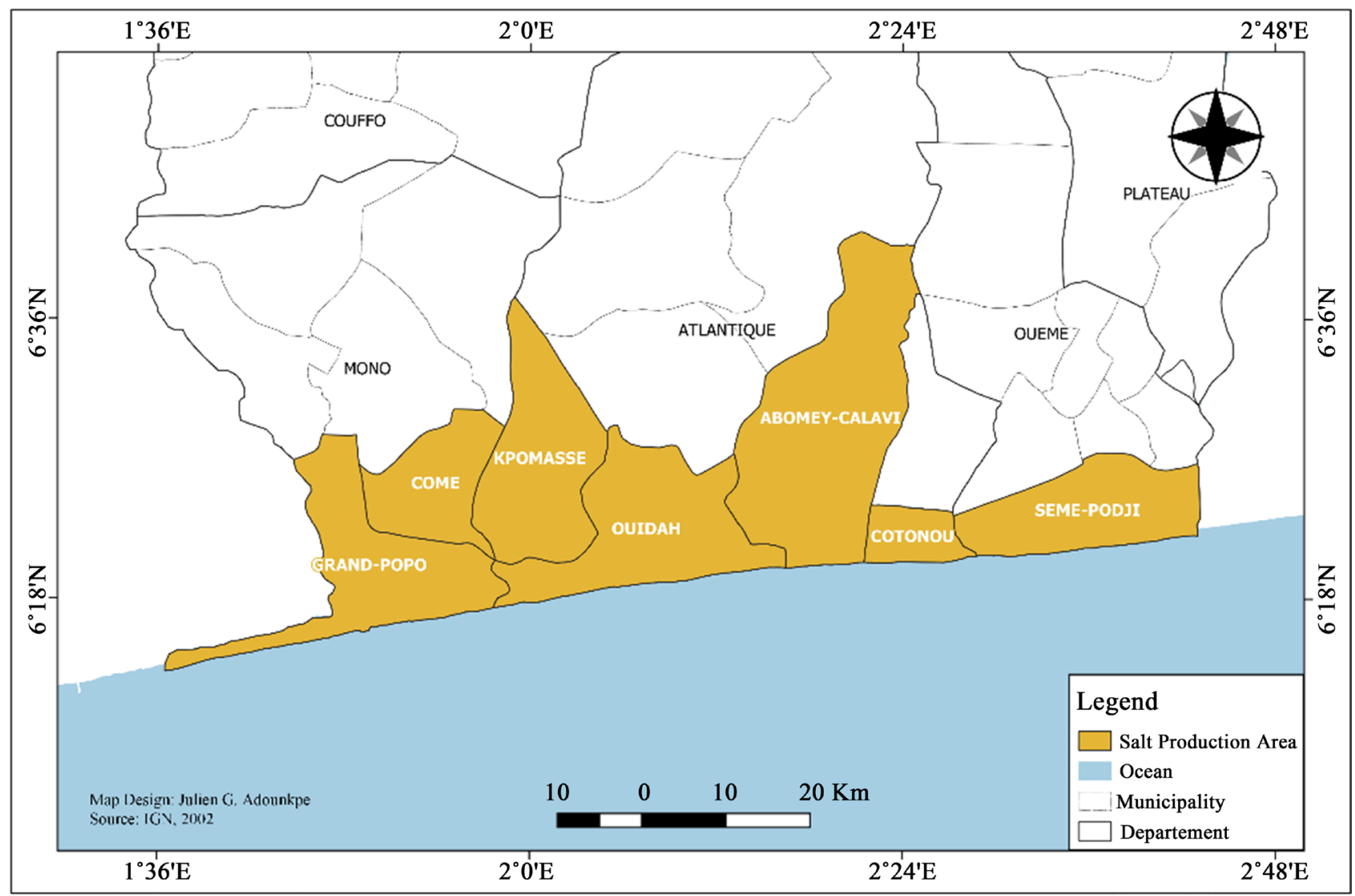

Figure 1. Study area showing the six municipalities in which table salt is harvested in south Benin Republic.

Table salt harvesting activities are fundamentally developed at the coast, in Southern Benin Republic, along the shoreline, for a distance of about $110 \mathrm{~km}$, spreading from the Municipality of Sèmè Kpodji ( $6^{\circ} 22^{\prime} 00^{\prime \prime}$ North, $2^{\circ} 37^{\prime} 00^{\prime \prime}$ East) in the East to the Municipality of Grand Popo (6 $6^{\circ} 17^{\prime} 00^{\prime \prime}$ North, $1^{\circ} 50^{\prime} 00^{\prime \prime}$ East) to the West. The total surface area of Sèmè Kpodji is $250 \mathrm{~km}^{2}$, Abomey Calavi 650 $\mathrm{km}^{2}$, Ouidah $364 \mathrm{~km}^{2}$, Kpomasse $305 \mathrm{~km}^{2}$, Comè $153 \mathrm{~km}^{2}$, and Lokossa 290.1 $\mathrm{km}^{2}$ (Figure 1).

The climate of the region is subtropical, hot, and humid. Annual rainfall in the coastal area averages $1360 \mathrm{~mm}$ (53.5 in), not particularly high for coastal West Africa. The region has two rainy and two dry seasons. The principal rainy season is from April to late July, with a shorter, less intense rainy period from late September to November. The main dry season is from December to April, with a short cooler dry season from late July to early September. Temperatures and humidity are high along the tropical coast. The average maximum temperature is $31^{\circ} \mathrm{C}\left(87.8^{\circ} \mathrm{F}\right)$; the minimum is $24^{\circ} \mathrm{C}\left(75.2^{\circ} \mathrm{F}\right)$. Agriculture, fishing, and small trade are the major economic activities of the study area.

\subsection{Methods}

In the framework of the launch of FOCUSED-Benin project, the $5^{\text {th }}$ work package of YES-PV NIGBEN, funded by the German Ministry of High Education 
and Research, approximately one hundred stakeholders in the field of agricultural production and salt harvesting in Benin Republic gathered together to reflect on the impacts of agricultural postharvest loss and salt production on the environment. The discussion was to find ways to improve the rural life quality and reduce anthropogenic pressure on the mangrove. This launch was an opportunity to get to know the stakeholders in the field of salt production in Benin Republic. During the discussions, a wealth of information pertaining to table salt harvesting in Benin Republic was collected.

A thorough literature review related to salt production worldwide was carried out.

The identification of salt harvesting associations operating in Benin Republic was made thanks to the salt producers that attended the kick-off meeting. Data collection was carried out by site visits where group meetings and interviews were used for the purpose. Data collected are related to the number of association members operating in the field of table salt traditional production, the objectives of the association, the creation date, methods of table salt production, a daily quantity of salt produced, salt demand, difficulties, source of energy used, quality and quantity of firewood daily, and the health issues the salt producers face.

\section{Results and Discussion}

\subsection{Some Characteristics of Salt Production in Southern Benin Republic}

All six municipalities of the south of Benin Republic where table salt is produced are covered in this study. The study area spread from the Nigeria-Benin border on the east, to the Benin-Togo border on the west, with a coastline of approximately $150 \mathrm{~km}$. Table 1 below summarizes the characteristics of each salt producing group.

\subsection{Technology Description}

For the salt production in Benin Republic, two technologies are used, based on the type of salty water collection and the source of energy [20].

A part from the associative group of Sèmè Okoun in the municipality of Sèmè Kpodji where seawater is used and the sun drying technology is deployed [21], the other five municipalities collect salty sand by thermosiphon, filter the salty sand by leachate and use fire wood as an energy source to evaporate the water [22].

\subsubsection{Sèmè Okoun Technology}

Seawater was poured on pan like plastic batches and sun-dried for 48 hours. Figure 2 depicts the technic.

- A $3.00 \mathrm{~m} \times 1.00 \mathrm{~m}$ crystallizer was made, the bottom of which is lined with black tarpaulin of rectangular section with a depth of $0.10 \mathrm{~m}$; the equilibrium of which is maintained with wood. 
Table 1. Table salt producing groups in southern Benin and characteristics.

\begin{tabular}{|c|c|c|c|c|c|c|}
\hline Municipality & Semè Kpodji & Abomey Calavi & Ouidah & Kpomassè & Comè & Grand-Popo \\
\hline Locality & Sèmè Oukoun & $\begin{array}{l}\text { Togbin Kpèvi } \\
\text { Togbin Gaho }\end{array}$ & Djègbadji & Gbezounmè & $\begin{array}{l}\text { Gbehoué, } \\
\text { Assouvicodji }\end{array}$ & Grand Popo, Gbécon \\
\hline Technology & $\begin{array}{l}\text { Drying } \\
\text { seawater on } \\
\text { plastic }\end{array}$ & $\begin{array}{l}\text { Salty sand } \\
\text { collection-water } \\
\text { filtering by } \\
\text { leachate and } \\
\text { evaporation }\end{array}$ & $\begin{array}{l}\text { Salty sand } \\
\text { collection-water } \\
\text { filtering by leachate } \\
\text { and evaporation }\end{array}$ & $\begin{array}{l}\text { Salty sand } \\
\text { collection-water } \\
\text { filtering by leachate } \\
\text { and evaporation }\end{array}$ & $\begin{array}{l}\text { Salty sand } \\
\text { collection-water } \\
\text { filtering by leachate } \\
\text { and evaporation }\end{array}$ & $\begin{array}{l}\text { Salty sand } \\
\text { collection-water } \\
\text { filtering by leachate } \\
\text { and evaporation }\end{array}$ \\
\hline $\begin{array}{l}\text { Source of } \\
\text { energy }\end{array}$ & sun & wood & wood & wood & wood & wood \\
\hline $\begin{array}{l}\text { Distance to } \\
\text { production site }\end{array}$ & $3500 \mathrm{~m}$ & $\begin{array}{l}\text { On site production } \\
2000 \mathrm{~m}\end{array}$ & On site production & $5000 \mathrm{~m}$ & $\begin{array}{l}\text { On site production } \\
5000 \mathrm{~m}\end{array}$ & $1000 \mathrm{~m}$ \\
\hline Working mode & Association & $\begin{array}{l}\text { Individual } \\
\text { Association }\end{array}$ & $\begin{array}{l}\text { Association } \\
\text { Individual }\end{array}$ & Individual & Individual & Individual \\
\hline Working days & 5 days/week & $\begin{array}{l}2 \text { days/week for the } \\
\text { association, } 4 \text { days } \\
\text { for individual } \\
\text { work }\end{array}$ & $\begin{array}{l}2 \text { days/week for the } \\
\text { association, } 4 \text { days for } \\
\text { individual work }\end{array}$ & 6 days/week & 6 days/week & 6 days/week \\
\hline $\begin{array}{l}\text { Number of } \\
\text { people }\end{array}$ & 34 & 28 & 38 & 48 & 24 & 19 \\
\hline
\end{tabular}

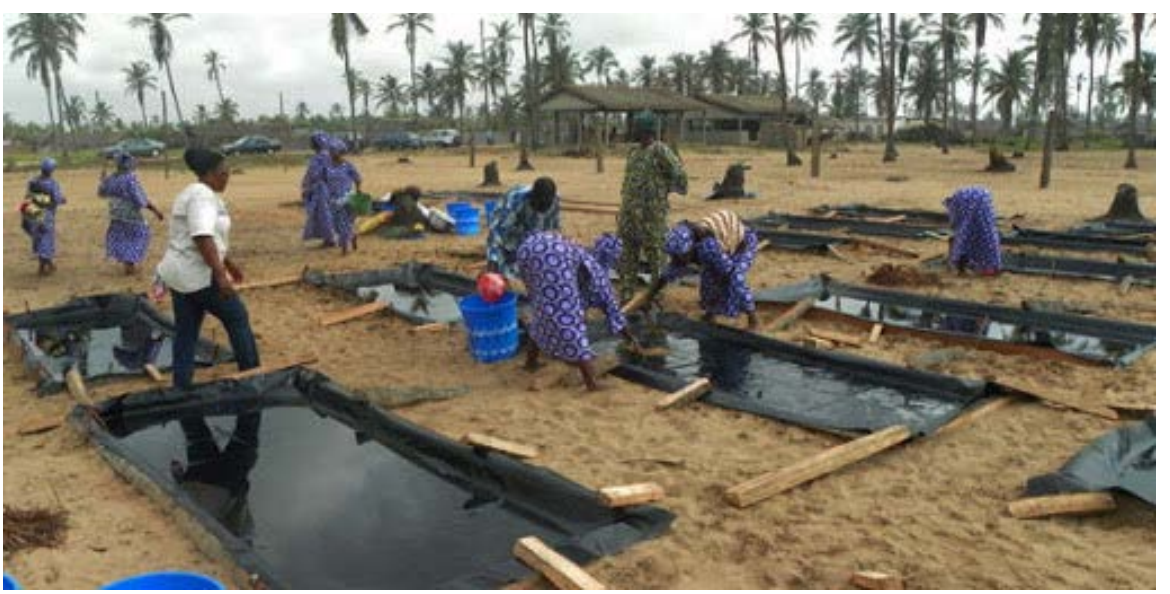

Figure 2. Photograph of women Association of Sèmè-Okoun installing the salt production plant which's fundamental component is the black tarpaulin held by woodbin.

- Seawater is poured in the crystallizer and allowed to evaporate under the action of the sun and wind, living behind crystallized salt.

A total of 48 crystallizers are set up within an area of $40 \mathrm{~m} \times 30 \mathrm{~m}$ fenced with local materials made from branches of oil palm trees.

Daily work, consisting of collecting seawater from the seashore to the salt plant, starts at 6 a.m. and ends by 9 a.m. By 4 p.m., a small amount of salt crystal is formed in the crystallizer.

The favorable period for this activity extends from November to May corresponding to the dry season. On average, $150 \mathrm{~kg}$ of salt is produced monthly for a total of $900 \mathrm{~kg}$ annually. The nutritive quality of the salt is determined by its 
iodine content. The chemical analyzes carried out by the Food and Applied $\mathrm{Nu}-$ trition Department (DANA) revealed that this salt is poor in iodine. Iodization of the harvested salt is one of the challenges faced by this group of women. Another challenge is the transportation of seawater from the seashore to the plant. Women have to carry on their head 50 L-containers filled with seawater for over $3 \mathrm{~km}$ on a sandy path. Installation of a pumping system as a solution is envisaged, but the technology is not well mastered because of the violent waves of the sea.

Seawater is a natural source of salt. It has salt at an average of 35 parts per thousand. The earliest method of salt production was the evaporation of seawater by the heat of the sun. This method was particularly suited to hot, arid regions near the ocean or near salty lakes and is still used in those areas. Seawater evaporation technology has been employed over time and generations [21]. The process for extracting salt from seawater is an ancient technology and involves evaporation within shallow ponds. One aspect of this technology is that shallow, water-proof ponds are dug out and connected to the sea by means of canals. A broad area and shallow depth allow a given volume of water to absorb more sunlight [22]. The pond is flooded, and then the canal is closed. The sun evaporates the water. As the water vaporizes, the salt remains behind, creating ever more saline water. Eventually enough of the water evaporates to leave behind a layer of sea salt crystals that can be harvested. Modern sea salt extraction operations typically have a number of these ponds concentrated in one location, separated by levees [21] [22] [23]. Unlike the technology employed at Sèmè Okoun, there is no canal connecting the sea to the ponds, and women have to collect seawater and transport it on their heads to fill up the ponds. Actually, one common challenge to seawater evaporation to harvest salt is rain. An untimely rain can ruin days of evaporation [21]. This is the reason for which at Sèmè Okoun, and elsewhere, salt harvesting from seawater evaporation is limited to the dry season period, or mostly developed in the dry areas. The vacuum pan evaporation is also used to produce salt [24].

\subsubsection{Other 5 Municipalities' Technology}

For the other five municipalities, table salt production occurs in marshy areas subject to frequent flooding. For this reason, the salt production runs from January to May, corresponding to the dry season on the coast. The production process consists of scraping and collecting salted sand from the ground (Figure 3 , Photo 2a) pouring this sand into baskets woven and watering it to drain the salt out, filtering by leachate and recovering salt water (Figure 3 ) Photo (2b), evaporating the salty water by cooking with wood fire and the crystallization of salt and its collection (Figure 3, Photo 2c).

The activity is carried out exclusively during the dry season, from January to May of each year due to the flooding nature of the activity areas. The production of salt on swampy sites starts from 6 a.m. and ends by 8 p.m. everyday. The daily production of salt is approximately $25 \mathrm{~kg}$. 


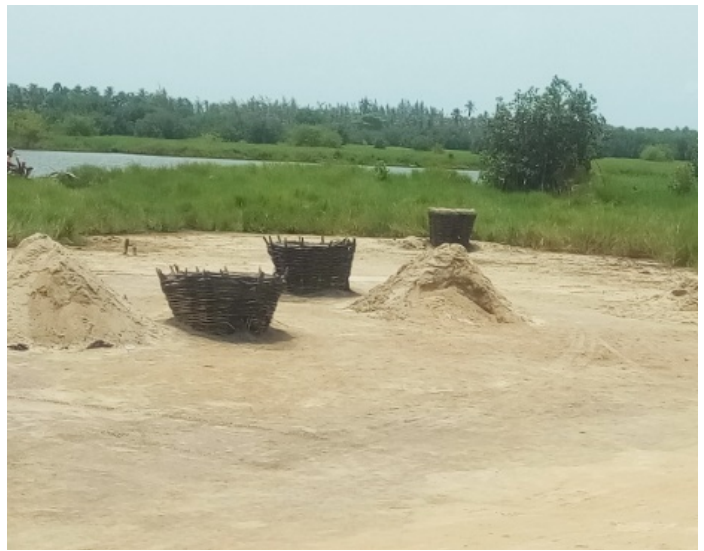

(a)

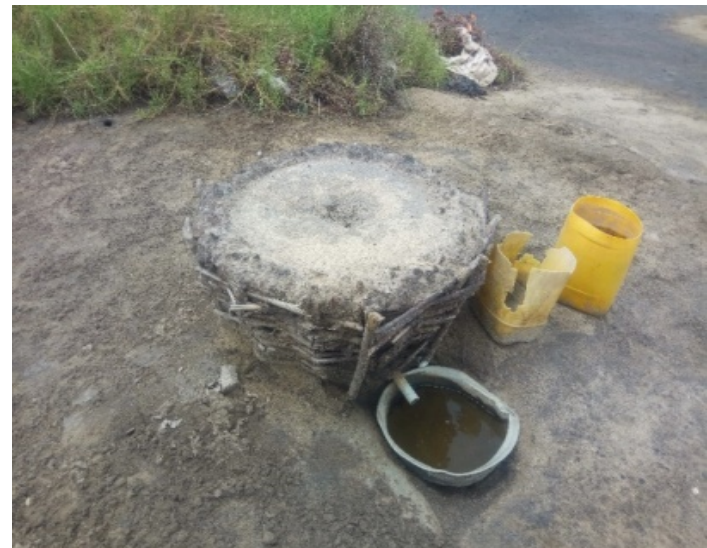

(b)

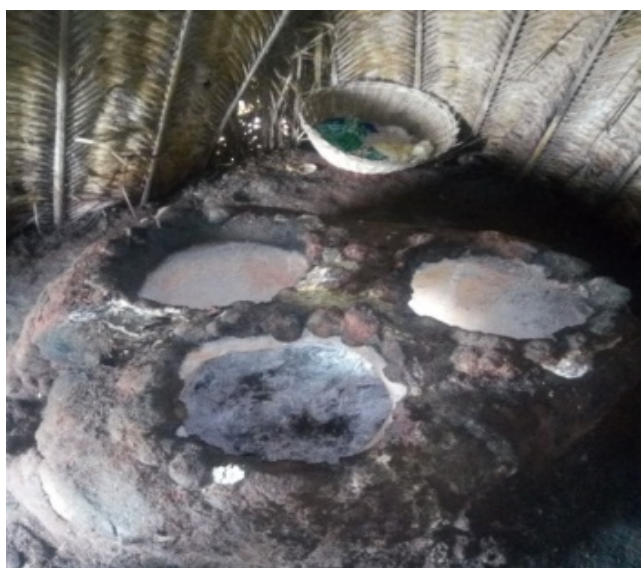

Figure 3. Photo 2: (a) Salty sand collecting field at Djègbadji; (b) Extraction of salt water by leaching salty sand; (c) Preparation of salt at Djègbadji (Ouidah)/usage of three-burner ovens.

Women salt producers not only face several health issues such as headaches, muscle and lumbar pain, fevers, cough, etc., but also the hardship of the activity (clearing of marshy sites, scraping and collecting salt sand, filtering), prohibitive prices for bundles of fire wood and low prices of the produced salt.

Brine evaporation by heating to harvest salt has been practiced as traditional way and employing firewood as energy source. Brine from salt wells is boiled to produce salt at Bo Kluea, Nan Province, Thailand, as it is done in Pakistan [25]. This is a very rudimentary technic at familial level of production along with its environmental and health related issues. However, the salt production technic in south Benin Republic consisting of scratching salty soil, leaching the collected salty sand for brine, seems to be unique in the world. Literature reported on seawater evaporation [26], salt extraction from the vast sedimentary deposits, digging salt from ground. However, the technique of scratching thermosiphon salty soil is not reported in the literature, to the best of our knowledge. Women salt producers clearly pointed at the use of firewood to heat brine for salt harvesting being the principal cause of sickness resulting in respiratory discomfort, troubles in sight, coughing, headache, and pulmonary disease. 


\subsection{Challenges Facing Table Salt Producers}

Besides the limited period of salt production and the varying prices of salt on the market, all salt producers face challenges related to the technology deployed.

\subsubsection{The Group of Women at Sèmè Okoun}

The women at Sèmè Okoun use direct sun drying technology for table salt production. This requires specific training and initial high investment costs. In 2012, the group, made of about 20 women, benefited three-week training sessions from a European NGO that helped them acquire the technique of salt production on tarpaulins. The financial needs to purchase the tarpaulins, working materials, wood frame, and to settle the plant, were satisfied partially by individual contributions and support from the Mayor of Sèmè-Kpodji through the Funds for the Development of Municipalities, the FADEC.

The distance from the seawater collection at the seashore to the salt production site, about three kilometers, represents a major difficulty. To fully develop this activity, the group of women needs to secure land along the seashore. This requires heavy investment. With the current technology deployed at Sèmè Okoun, salt production is not a year-round business. It lasts just four months after which women become jobless. This precarity deteriorates their financial situation.

\subsubsection{The Table Salt Producers of the Other Five Municipalities}

The table salt production within the other groups is very rudimentary. The women use firewood to evaporate saltwater to crystalize salt. The challenges that women face are several folds: precarity of the utensils, health issues, distance to carry sand. The sand scraping hoe cuff is so short that women have to be bent for hours. This causes them to experience musculature pains. Making a wood fire to evaporate saltwater exposes them to the combustion generated particles, resulting in headaches, fever, coughing, even some pulmonary complications. Women, most of the time, have to travel long distance, four to five kilometers carrying a heavy load of salty sand on their heads. This resulted in muscle and lumbar pain. Additionally, the prohibitive prices for bundles of wood and the low prices of salt do not help the economic situation of salt producers. Moreover, the utensils are frequently damaged by corrosion (Figure 4(a)) and cannot survive a producing season.

Overall, traditional salt production can face sanitary issues, from scraping the salty soil, to filtering the salt water, distilling it, and storing the obtained salt. A total lake of hygiene was observed within the five municipalities where the traditional salt harvesting method is in use. Figure 4(b) depicts a bundle of crystalized salt, stored in poor hygienic conditions.

\subsection{The Mangrove Destruction in Relationship with Table Salt Production and Health Issues}

On the photographs below and elsewhere in this paper, it is clear that table salt 
production consumes wood for various purposes. Women salt producers also face some health issues due to the salt production activies.

\subsubsection{Mangrove Destruction}

The table salt production technic that massively contributes to the mangrove destruction in the coastal zone of Benin Republic is the one using fire wood as source of energy to evaporate the brine. From Table 1, $82.20 \%$ of table salt producers employ wood from the cutting down of mangrove for several purposes. The leaching baskets used to obtain the brine are made out of mangrove (Figure 3(a) for empty baskets, and Figure 3(b) for loaded basket). Figure 5 depicts the type of mangrove used to make leaching baskets Figure 5(a), the basket Figure 5(b). Mangrove wood is also used to construct the shelters (Figure 5(c), Figure 5(d)) and to evaporate brine (Figure 5(e)). A substantial reduction in mangrove

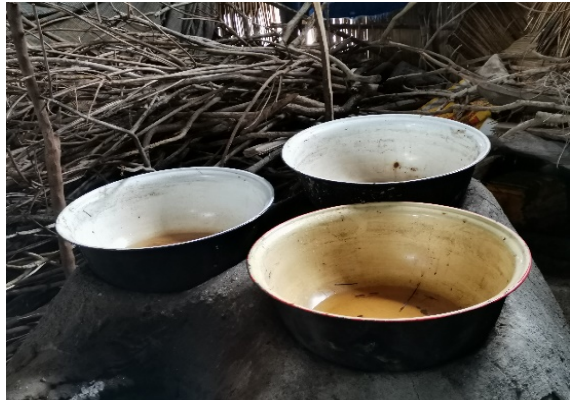

(a)

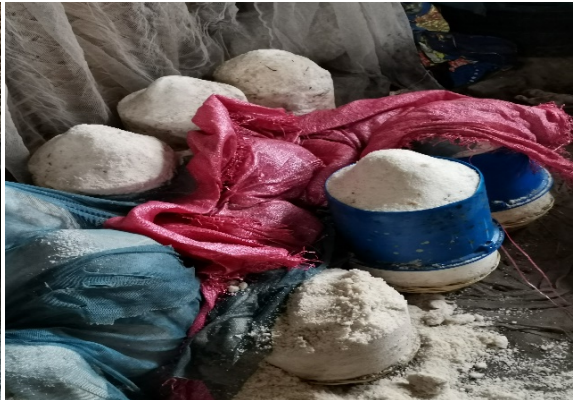

(b)

Figure 4. Photographs of salt fire-crystalized utensils (a) and a bundle of crystalized salt, ready to be sold (b). These photographs portray the poor hygienic conditions of traditional table salt harvesting in Republic of Benin.

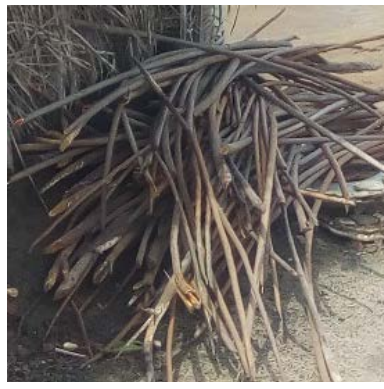

(a)

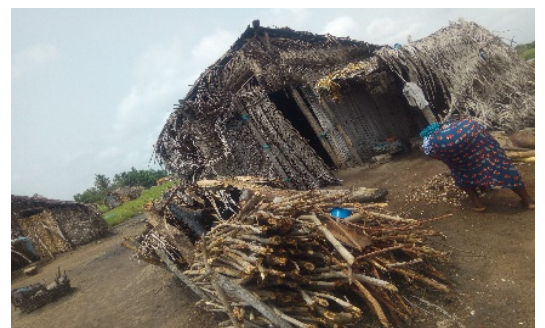

(d)

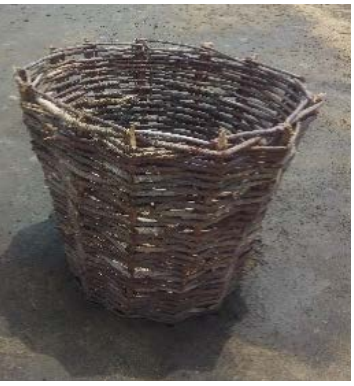

(b)

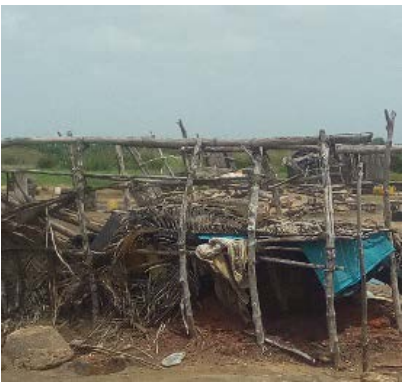

(c)

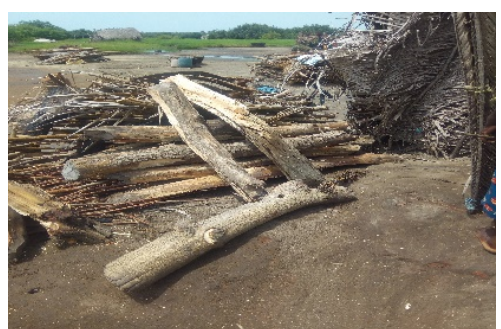

(e)

Figure 5. Mangrove wood (a) used to make leaching baskets (b), to build shelters ((c), (d)), to make fire for brine evaporation (e). 
surface area was attributed to table salt production on the coastal zone of Benin Republic. Paradis and Adjanohoun reported on the impacts of salt production on the vegetative mangrove in Low-Dahomey [27]. In 2006, Bamisso M. reported a degradation rate of the Benin Republic coastal mangrove of 2.4 ha per year induced in part by the dynamics of water courses and bodies, the erosion of the banks as well as various forms of exploitation such as salt farming, fuelwood, market gardening carried out by the local populations [28].

According to Orekan et al., the reduction of the mangrove surface area from 6930 ha in 2005 to 5871 ha in 2015, representing respectively $16.31 \%$ o and $13.82 \%$ of the Beninese littoral surface area is due to, among others, table salt traditional production [13].

Various causes lead to substantial mangrove reduction. In a study recently conducted by Gordon et al., a $2.8 \%$ reduction in mangrove surface area over 50 years is predicted [29], due to human settlement, and infrastructure. Aquaculture, basically shrimp production will take-up this reduction to an additional annual $0.75 \%$ of the mangrove surface area, resulting in a $54 \%$ net reduction over 100 years, after regrowth of abandoned aquaculture areas [29].

However, mangroves hold important functions in the ecosystem that is very beneficial both to human and the environment. Mangroves are home to significant biodiversity [30] [31] and play the essential role of nursery for many fish species [32] [33]. Mangrove can limit erosion and have a purification effect by filtering macro-waste [34]. They contribute to the water and nutrient cycle [35] [36]. In urban areas, they act as a sponge by absorbing excess water that could cause flooding [37]. Mangroves also act as coastal barriers or defenses against storms [19] [38] and sea level rise under certain conditions [39]. Mangroves typically provide some protection from extreme coastal events, such as tsunamis and cyclones. It was estimated an $8 \%$ reduction in the severity of impacts of the 2004 tsunami in coastal areas with mangroves [19]. Mangroves capacity to sequester carbon is key contributor to greenhouse gases reduction, the combat against climate change [29] [40].

\subsubsection{Health Issues}

The health issues faced by the women salt producers are dependent on the type of technology deployed. As previously highlighted, two major technics are at use for table salt production in southern Benin Republic.

For the one that uses solar radiation and wind to evaporate seawater on tarpaulins, the health complaints by almost $100 \%$ of association members are basically related to muscular and joint pains, headache, and fatigue. This is understandable since women salt producers have no mechanical means for bringing seawater from the sea to the salt production site distant of about $3 \mathrm{~km}$. Those ladies have to carry heavy load of seawater on their heads, and walk on the seashore sand to the production site.

As far as the evaporation of brine by using fire wood technic, in addition to muscular and joint pains reported by $100 \%$ of the workers, some of them expe- 
rience other sicknesses such as respiratory discomfort, troubles in sight, coughing, headache, and pulmonary disease.

\section{Conclusions}

In Benin Republic, the extraction of sea or lagoon salt is a female-dominated activity in the southern municipalities of Sèmè Kpodji, Abomey-Calavi, Ouidah, Kpomassè, Comè, and Grand-Popo. Except for the municipality of Sèmè Kpodji where sun drying of seawater on tarpaulins is used, the traditional extraction techniques in the other five municipalities are almost similar with small nuances. It consists in scraping salty sand, getting salty water by lixiviated filtering, evaporating the water to crystalize salt using firewood. The study shaded light on the challenges that table salt producers face, namely, the hardship of work, health issues, the rudimentary of the utensils employed, the seasonal production, and the financial issues. Above all those challenges, the mangrove ecosystem is destroyed. This not only endangers the living species with some of them disappearing, but also reduces or annihilates the ecosystem's functions. Individual salt producers are eager to be working in a cooperative and open to approaches that alleviate their pain and increase their revenue.

Detailed study of the thermodynamics of the traditional salt production will help to document the mechanism and the process so as to evaluate the kinetic, and the quantity of wood used per kilogram of salt production. This will help to precisely determine the share that the table salt traditional production takes in mangrove destruction, and the economic aspects of the production.

\section{Data Availability}

The data used to support the findings of this study are available from the corresponding author upon request.

\section{Authors' Contributions}

J. Adounkpe conceptualized the study, developed the methodology, performed formal analysis and investigation, and wrote the original draft. C. Agboton conceptualized the study, developed the methodology, performed field work analysis and investigation such as interviewing salt producers, W. Amoussa conceptualized the study, and developed the methodology, C. Ahouannou conceptualized the study, and developed the methodology, B. Kounouhewa conceptualized the study, and developed the methodology, reviewed and edited the article, B.Sinsin reviewed and edited the article.

\section{Acknowledgements}

The authors thank the German Ministry of Higher Education and Scientific Research (BMBF) for its financial support through the Institute of Energy and Climate Research, Julich grant TTB/B1806.05.18. 


\section{Conflicts of Interest}

The authors declare no conflicts of interest regarding the publication of this paper.

\section{References}

[1] Ralston, R.H., Hills, J.M. and Wood, F.O. (2020) "Salt”. Encyclopedia Britannica. https://www.britannica.com/science/salt

[2] Kurlansky, M. and Schindler, S.D. (2006) The Story of Salt G.P. Putnam's Sons, New York.

[3] Breslin, P.A.S. and Beauchamp, G.K. (1997) Salt Enhances Flavour by Suppressing Bitterness. Nature, 387, Article No. 563. https://doi.org/10.1038/42388

[4] Loh, K.Y. (2008) Know the Common Substance: Table Salt (Sodium Chloride, $\mathrm{NaCl}$ ). Malaysian Family Physician, 3, Article No. 174.

[5] Cook, N.R., Cutler, J.A. and Obarzanek, E. (2007) Long Term Effects of Dietary Sodium Reduction on Cardiovascular Disease Outcomes: Observational Follow-up of the Trials of Hypertension Prevention (TOHP). British Medical Journal, 334, Article No. 885. https://doi.org/10.1136/bmj.39147.604896.55

[6] Hooper L., Bartlett C., Davey S.G. and Ebrahim S. (2004) Advice to Reduce Dietary Salt for Prevention of Cardiovascular Disease. Cochrane Database of Systematic Reviews, No. 1, Article No. CD003656.

[7] IOM (Institute of Medicine) (2013) Sodium Intake in Populations: Assessment of Evidence. The National Academies Press, Washington DC.

[8] USDA (US Department of Agriculture) (2015) Scientific Report of the 2015 Dietary Guidelines Advisory Committee. US Department of Agriculture. Washington DC, 7.

[9] Bolen, W.P. (2019) Salt US Geological Survey, Mineral Commodity Summaries (Report). US Geological Survey, Reston.

[10] Freedonia Group (2014) World Salt: Industry Study with Forecasts for 2018 \& 2023. https://www.freedoniagroup.com/brochure/31xx/3199smwe.pdf

[11] Weller, O. (2002) The Earliest Rock Salt Exploitation in Europe: A Salt Moutain in Spanish Neolithic. Antiquity, 76, 317-318.

https://doi.org/10.1017/S0003598X0009030X

[12] McDowell, L. (2017) Mineral History: The Early Years'. First Edition Design Publishing, Inc., Sarasota.

https://books.google.co.uk/books?id=Z4otDwAAQBAJ\&printsec=frontcover\&redir esc $=\mathrm{y} \# \mathrm{v}=$ onepage $\& \mathrm{q} \& \mathrm{f}=$ false

[13] Orekan, V., Plagbeto, H., Edea, E. and Sossou M. (2019) Évolution actuelle des écosystèmes de mangrove dans le littoral béninois. Conférence OSFACO: Des images satellites pour la gestion durable des territoires en Afrique, Cotonou, Bénin, Mar 2019, ffhal-02189536.

[14] Orekan, V., Toffi, M.D., Hohodji, I.A. and Plagbeto, H.A. (2018) Dynamique spatiale des écosystèmes de mangrove dans l'arrondissement d'Avlo-Grand-Popo sur le Littoral du Bénin, International Journal of Scientific \& Engineering Research, 9, 487-488.

[15] Donato, D., Kauffman, J.B., Kanninen, M., Kurnianto, S., Murdiyarso, D. and Stidham, M. (2011) Mangroves among the Most Carbon-Rich Forests in the Tropics. Nature Geoscience, 4, 293-297. https://doi.org/10.1038/ngeo1123 
[16] WRI (World Resources Institute) (2019) Climate Watch Data Explorer. CAIT Climate Data Explorer. World Resources Institute, Washington DC. https://www.wri.org/our-work/project/cait-climate-data-explorer

[17] Alongi, D. (2012) Carbon Sequestration in Mangrove Forests. Carbon Management, 3, 313-322. https://doi.org/10.4155/cmt.12.20

[18] Armah, A.K., Diame, A., Ajonina, G. and James, K. (2019) Protection des mangroves: Le rôle du Réseau africain des mangroves. Nature \& Faune, 24, 27-51.

[19] Juan, L.B., Cadisch, G., Dercon, G., Dewi, S., Joshi, L., Marohn C., van Noordwijk, M. and Piepho, H. (2011) Influence of Coastal Vegetation on the 2004 Tsunami Wave Impact in West Aceh. Proceedings of the National Academy of Sciences of the United States of America, 108, 18612-18617.

https://doi.org/10.1073/pnas.1013516108

[20] Cunningham, S. (1989) Wicca: A Guide for the Solitary Practitioner. Llewellyn Worldwide, Woodbury, 60, 63, 104, 113.

[21] Thomas, E. (n.d.) How Is Salt Extracted from the Sea? https://www.leaf.tv/articles/how-is-salt-extracted-from-the-sea/

[22] NASA (National Aeronautics and Space Administration) (2009) Salt Ponds, South San Francisco Bay. NASA Visible Earth, 11 August 2009. NASA (National Aeronautics and Space Administration), Washington DC.

[23] Williams, P.D., Guilyardi, E., Madec, G., Gualdi, S. and Scoccimarro, E. (2009) The Role of Mean Ocean Salinity in Climate. Dynamics of Atmospheres and Oceans, 49, 108-123. http://meetings.copernicus.org/ems2009/

[24] Adler, A.J., Taylor, F., Martin, N., Gottlieb, S., Taylor, R.S. and Ebrahim, S. (2014) Reduced Dietary Salt for the Prevention of Cardiovascular Disease. The Cochrane Database of Systematic Reviews, No. 12, Article No. CD009217.

[25] Pennington, M. (2005) Pakistan Salt Mined Old-Fashioned Way. The Seattle Times. https://www.seattletimes.com/nation-world/pakistan-salt-mined-old-fashioned-way/

[26] He, F.J., Li, J. and Macgregor, G.A. (2013) Effect of Longer Term Modest Salt Reduction on Blood Pressure: Cochrane Systematic Review and Meta-Analysis of Randomised Trials. British Medical Journal, 346, Article No. f1325. https://doi.org/10.1136/bmj.f1325

[27] Paradis, G. and Adjanohoun, E. (1974) L'impact de la fabrication du sel sur la végétation de mangrove et la géomorphologie dans le Bas-Dahomey. Annales de P Université d Abidjan, Série E, 7, 599-612.

[28] Bamisso, M. (2006) Caractérisation et gestion des écosystèmes de mangrove dans le littoral béninois. Mémoire de maîtrise. Faculté des Lettres, Arts et Sciences Humaines. Université d'Abomey-Calavi, Benin, 68 p.

[29] Gordon, S., Cooley, D., Brown, B., Fritriana, R. and Hyman, E. (2020) Cost-Benefit Analysis of Mangrove Conservation versus Shrimp Aquaculture in Bintuni Bay and Mimika, Indonesia. Prepared for the United States Agency for International Development, Crown Agents USA and Abt Associates, Washington DC.

[30] Field, C., Osborn, J., Hoffman, L., Polsenberg, J., Ackerly, D., Berry, J. and Mooney, H. (1998) Mangrove Biodiversity and Ecosystem Function. Global Ecology \& Biogeography Letters, 7, 3-14. https://doi.org/10.2307/2997693

[31] Nagelkerken, I.S.J.M., Blaber, S.J.M., Bouillon, S., Green, P., Haywood, M., Kirton, L.G. and Somerfield, P.J. (2008) The Habitat Function of Mangroves for Terrestrial and Marine Fauna: A Review. Aquatic Botany, 89, 155-185.

https://doi.org/10.1016/j.aquabot.2007.12.007 
[32] Manson, F.J., Loneragan, N.R., Skilleter, G.A. and Phinn, S.R. (2005) An Evaluation of the Evidence for Linkages between Mangroves and Fisheries: A Synthesis of the Literature and Identification of Research Directions. In: Hawkins, S.J., Allcock, A.L., Bates, A.E., Firth, L.B., Smith, I.P., Swearer, S.E., et al., Eds., Oceanography and Marine Biology, CRC Press, Boca Raton, 493-524.

[33] Aburto-Oropeza, O., Ezcurra, E., Danemann, G., Valdez, V., Murray, J. and Sala, E. (2008) Mangroves in the Gulf of California Increase Fishery Yields. Proceedings of the National Academy of Sciences of the United States of America, 105, 10456-10459. https://doi.org/10.1073/pnas.0804601105

[34] Gedan, K.B., Kirwan, M.L., Wolanski, E., Barbier, E.B. and Silliman, B.R. (2011) The Present and Future Role of Coastal Wetland Vegetation in Protecting Shorelines: Answering Recent Challenges to the Paradigm. Climatic Change, 106, 7-29. https://doi.org/10.1007/s10584-010-0003-7

[35] Allen, D.E., Dalal, R.C., Rennenberg, H., Meyer, R.L., Reeves, S. and Schmidt, S. (2007) Spatial and Temporal Variation of Nitrous Oxide and Methane Flux between Subtropical Mangrove Sediments and the Atmosphere. Soil Biology and Biochemistry, 39, 622-631. https://doi.org/10.1016/j.soilbio.2006.09.013

[36] Gleeson, J., Santos, I.R., Maher, D.T. and Golsby-Smith, L. (2013) GroundwaterSurface Water Exchange in a Mangrove Tidal Creek: Evidence from Natural Geochemical Tracers and Implications for Nutrient Budgets. Marine Chemistry, 156, 27-37. https://doi.org/10.1016/j.marchem.2013.02.001

[37] Jain, A.K. (2006) The Concept of Bio-Drainage in Flood Prevention and the Avoidance of Water Scarcity. International Journal of Environmental Studies, 63, 39-48. https://doi.org/10.1080/00207230500410224

[38] Ghazali, N., Zainuddin, K., Zainal, M.Z., Dali, H.M., Samad, A.M. and Mahmud, M.R. (2016) The Potential of Mangrove Forest as a Bioshield in Malaysia. 2016 IEEE 12 th International Colloquium on Signal Processing \& Its Applications (CSPA), Melaka, 4-6 March 2016, 322-327. https://doi.org/10.1109/CSPA.2016.7515854

[39] Lovelock, C.E., Cahoon, D.R., Friess, D.A., Guntenspergen, G.R., Krauss, K.W., Reef, R. and Saintilan, N. (2015) The Vulnerability of Indo-Pacific Mangrove Forests to Sea-Level Rise. Nature, 526, 559-563. https://doi.org/10.1038/nature15538

[40] Kauffman, J.B. and Bhomia, R.K. (2017) Ecosystem Carbon Stocks of Mangroves across Broad Environmental Gradients in West-Central Africa. PLoS ONE, 12, e0187749. https://doi.org/10.1371/journal.pone.0187749

\section{List of the Accronyms}

BMBF: German Ministry of Education and Scientific Research

DANA: Direction de l'Alimentation et de la Nutrition Appliquée

FADEC: Fonds d'Aide au Developpement Economique des Communes

FOCUSED-Benin: Food Conservation by Utilizing Solar Energy for Drying

YES-PV NIGBEN: Yield Analyses and Socio-economic Impact Assessment of Photovoltaic and Photovoltaic-supported food and energy hybrid Systems in Tropical Nigerian-Beninese Climate. 